\title{
COLLABORATION-BASED SUPPORT PROVISION MODELS FOR CHILDREN WITH SPECIAL EDUCATIONAL NEEDS
}

\author{
Rita Kantanavičiūtè \\ Siauliai University, Lithuania \\ Laima Tomėnienè \\ Siauliai University, Lithuania
}

\begin{abstract}
The article aims to reveal collaboration-based support provision models for a child with special educational needs and his/her family in Lithuania. The qualitative research method used was a semi-structured interview. The participants of the research were special educators and speech therapists providing support to school-age children with special educational needs. The obtained results of the research helped to reveal children support specialists' attitude towards collaboration-based support provision to a child with special educational needs and his/her family in Lithuania. The research revealed the importance and opportunities of the implementation of interprofessional coordinated support based on interprofessional collaboration, referring to the experience of speech therapists and special educators providing support to a school-age child with special educational needs and his/her family.

Keywords: collaboration-based support, interprofessional collaboration, multiprofessional support, special educational needs.
\end{abstract}

\section{Introduction}

The relevance and problem of the research. In the recent decades, both in international and national context, collaboration-based support concepts and models for persons with special educational needs have been undergoing change. Attention is more and more focused on inclusive education of children with various needs, child and family empowerment, systemic support, the complexity, flexibility, and accessibility of services is emphasized (Carpenter, 2007; Vanclay, 2003; Soriano, 2005; Nolte, 2005; Ališauskienè, 2010). Attitude, concepts, methodologies, and the notions used are changing, the focus is being shifted to the creation of equal conditions for everyone regardless of the level of disability or special educational needs (Miltenienè \& Melienè, 2010).

In Lithuania, there is a lack of research that would reveal collaboration-based support provision models for a child with special educational needs and his/her family. While providing support to a child with special educational needs, it is 
important that specialists representing different professions provide complex services emphasizing active relations among various specialists and pedagogues, who strive to jointly solve problems that emerge in practice. Therefore, it is relevant to investigate the peculiarities of collaboration between child support specialists and pedagogues, and the peculiarities of special pedagogical support provided to children with special educational needs as well as challenges arising in practice.

The experience of the European countries shows (Davis \& GavidiaPayne, 2009) that family-centred practice is considered as an ideal and target model of early child and family support. In the authors' opinion, collaboration helps to unite persons with special educational needs (SEN), their family members, specialists in various fields (speech therapists, special educators, psychologists, neurologists, pediatricians, occupational therapists, etc.), and possible resources of the participants of the communicative system in order to distribute responsibility and commitments that condition the efficiency of the support for children. It is evident that in this context communication in a particular team of specialists and pedagogues is a complicated process, because the specialists of various professions differently understand the problems of the education of a child with SEN and the problems of overcoming the disorder, as well as the chosen methods of support. In the context of collaboration-based support provision to a child and his/her family, the collaboration among specialists creates the preconditions for partnership-based interrelations, complex service provision, and interprofessional development (Baker \& Donnelly, 2001; Olenic et al., 2010; Reeves et al., 2010).

The object is collaboration-based support provision models for a child with special educational needs and his/her family.

The aim is to reveal collaboration-based support provision models for a child with special educational needs and his/her family in Lithuania.

Participants of the research. Speech Therapists who work in Pedagogical Psychological Services (PPS) $(\mathrm{N}=20)$ and special educators, providing support to school-age children with special educational needs $(\mathrm{N}=20)$.

\section{Collaboration models - theoretical substantiation}

In order to jointly solve the problems of complex character arising in practice, it is important for the representatives of different professions to collaborate, share roles and responsibilities, and combine their goals (Kairiené, 2012; Hall \& Weaver, 2001; Hammick \& Freeth, et al., 2009). Specialists of different professions working separately cannot ensure suitable support that would contribute to the welfare of a child or a family. The combination of the specialists representing different professions in a team creates the opportunities to provide 
services effectively, i.e., in a complex, integral, and synergistic way, therefore, collaboration-based support is important, which is defined by active relations among the specialists of one discipline working together and striving to solve all the problems that arise in practice. The specialist's duty is to help families to achieve their aims, to know families and their needs as well as possible, to know his/her own attitudes as a specialist, and admit his/her limitations (Kantanavičiūté, 2018).

Referring to the concept map of support provision by Olenick, Ryan Allen, and Raymond Smego (2010), work in a team reflects the development of knowledge, scientific research and functional meanings of teaching/learning. In the authors' opinion, two main models of support provision are predominant:

1) Multiprofessional support model is related to several professions, when the participants of support provision act next to each other, separately, not interacting among themselves. The profession characterizing every circle indicates separate accountability, when there is a lack of specialists' communication and knowledge sharing. It is pointed out that every specialist is a professional in his/her field and acts without leaving the boundaries of his/her profession. The interaction of every specialist with the child and his/her family is observed, however, the lack of specialists' interaction among themselves is felt.

2) Support provision in interprofessional teams of specialists, when specialists representing different professions strive for common aims, together organize the learning process, search for common solutions and share responsibility. This model of support provision unites the specialists of the professions of various fields and the participants of support receiving into a single whole. Specialists and pedagogues closely interact with each other focusing on the support provision to a child and his/her family.

Referring to the principles of interprofessional practice, Villa, Thousand (2005), Kauffman, Hallahan (2005) present the main models and directions of support provision:

- paradigm of support encourages to focus on the community partnership, a person with disability, the needs of his/her family, friends, community;

- $\quad$ self-representation - people with disability organizing political actions can change laws, attitudes and the support process that conditions their life;

- $\quad$ person-centred approach - a person with disabilities decides upon the most important goals of his/her life, and specialists providing support must help him/her strive for these goals; 
- family-centred support - family is considered as the centre of all people's life. Acknowledging the rights of a person with disability, his/her family is involved into all the stages of intervention giving its members the feeling of empowerment and partnership;

- decline in the role of specialists - specialists' domination is replaced by the focus on versatile needs of a person to whom support is provided;

- accountability - theoretically interprofessional practice corresponds to the holistic model of human development, however, there are not enough data that would confirm that interprofessional practice is more effective than other models of support.

The collaboration between the specialists of various professions, pedagogues, and parents helps to construct a conceptual support model uniting scientific and practical knowledge. The persons, whose aim is to define a joint action plan that will help to solve problems in the most effective way, are involved into the process of interprofessional support. It means that the contribution of all the participants in striving for common goals must be equal, and the collaboration process must be based on respect and agreement.

\section{The methodology of the research}

The research was conducted referring to qualitative research approach. The research method used was a semi-structured interview. The data obtained during the interview were analysed distributing them into categories. The method of content analysis was applied for qualitative data processing. The questions of the prepared semi-structured interview were based on the analysis of scientific literature and the phenomenon under investigation. Having prepared the questions of a semi-structured interview for speech therapists, special educators, and teachers, in order to ensure the validity of the questionnaire of the interview, in the preparation for the research an exploratory study was conducted.

\section{The results and conclusions of the research}

The obtained results of the research helped to reveal child support specialists' (speech therapists' and special educators'), working in Pedagogical Psychology Services (PPS) and general education schools attitude towards collaboration-based support provision to a child with special educational needs and his/her family in Lithuania.

Table 1 shows the data obtained from interviews with PPS speech therapists regarding the providing of assistance to children with special educational needs. 
Table 1 Category: Interprofessional support model (opinion of the speech therapist)

\begin{tabular}{|c|c|}
\hline Subcategory (team composition) & Affirmations of cooperation / non-cooperation \\
\hline $\begin{array}{l}\text { Special educator, speech and language } \\
\text { therapist, social educator, two } \\
\text { psychologists }(\mathrm{N}=5) \text {. }\end{array}$ & $\begin{array}{l}\text { The team performs evaluations every day, teamwork, } \\
\text { discussions take place in the afternoon, and the findings } \\
\text { of the evaluation of each specialist are discussed and the } \\
\text { final evaluation conclusion (L1) is formed. }\end{array}$ \\
\hline $\begin{array}{l}\text { Speech therapist, special educator, } \\
\text { psychologist, social educator }(\mathrm{N}=4) \text {. }\end{array}$ & $\begin{array}{l}\text { We cooperate on an equally (L20). Complex assessment } \\
\text { of the child, each practitioner evaluates his or her field, } \\
\text { discussing abilities and difficulties, and drawing } \\
\text { conclusions and recommendations is the work of the } \\
\text { entire team (L3). }\end{array}$ \\
\hline $\begin{array}{l}\text { Speech therapist, psychologist, special } \\
\text { educator, social educator. Parents }(\mathrm{N}=4) \text {. }\end{array}$ & $\begin{array}{l}\text { Each specialist expresses own observation and a general } \\
\text { conclusion is available (L4), (L18). }\end{array}$ \\
\hline $\begin{array}{l}\text { Speech therapist, special educator, social } \\
\text { educator, psychologist, teacher, public } \\
\text { health specialist }(\mathrm{N}=6) \text {. }\end{array}$ & $\begin{array}{l}\text { All specialists develop one single plan for coping with the } \\
\text { disorder (L5). }\end{array}$ \\
\hline $\begin{array}{l}\text { Teacher of the deaf and hearing impaired, } \\
\text { psychologist, special educator, social } \\
\text { educator, parents }(\mathrm{N}=5) \text {. }\end{array}$ & $\begin{array}{l}\text { The center of the whole team is the child and his parents } \\
\text { (L6). It is very important to present the results to the } \\
\text { parents, teachers and child development professionals } \\
\text { after the child assessment (L19). We do it together (L17). }\end{array}$ \\
\hline $\begin{array}{l}\text { Speech therapist, special educator, } \\
\text { psychologist, social educator }(\mathrm{N}=4) \text {. }\end{array}$ & $\begin{array}{l}\text { It is good to have someone to talk to, talk to, discuss any } \\
\text { difficulties, and discuss the educational achievements of } \\
\text { children (L7). }\end{array}$ \\
\hline $\begin{array}{l}\text { Psychologist, speech therapist, special } \\
\text { educator, neurologist }(\mathrm{N}=4) \text {. }\end{array}$ & $\begin{array}{l}\text { Provides preliminary conclusions to the child's parents } \\
\text { and educational institution. Work takes place in a team } \\
\text { (L8). }\end{array}$ \\
\hline $\begin{array}{l}\text { Psychologist, speech therapist, special } \\
\text { educator, social educator, neurologist. } \\
\text { Administration (Director) }(\mathrm{N}=6) \text {. }\end{array}$ & $\begin{array}{l}\text { We sit down at the table, the specialists and the parents of } \\
\text { the child. After the evaluation, the individual specialists } \\
\text { sit back and discuss together, writing the final conclusion } \\
\text { and recommendations. (L9). We also provide counseling, } \\
\text { if needed, to child educators, child support professionals } \\
\text { and parents (L16). }\end{array}$ \\
\hline $\begin{array}{l}\text { Psychologist, speech therapist, special } \\
\text { educator, social educator }(\mathrm{N}=4) \text {. }\end{array}$ & $\begin{array}{l}\text { Initially, children are assessed by each specialist } \\
\text { individually, and after evaluation we sit down to } \\
\text { formulate the final conclusions (L10). We are considering } \\
\text { how we will present the child assessment results to } \\
\text { parents and representatives of the School Child Welfare } \\
\text { Board (L2). We work as a team, so we deliver the child } \\
\text { assessment results in consultation (L15). }\end{array}$ \\
\hline $\begin{array}{l}\text { Psychologist, speech therapist, special } \\
\text { educator, social educator, neurologist } \\
(\mathrm{N}=5) \text {. }\end{array}$ & $\begin{array}{l}\text { Each performs their functions, then discusses and } \\
\text { reaches general conclusions (L11). }\end{array}$ \\
\hline $\begin{array}{l}\text { Speech Therapist, special educator, } \\
\text { psychologist, social educator, teacher of } \\
\text { the blind and visually impaired, teacher } \\
\text { of the deaf and hearing impaired, teacher } \\
(\mathrm{N}=6) \text {. }\end{array}$ & $\begin{array}{l}\text { First there is the discussion in the team. We discuss } \\
\text { conclusions, recommendations in general. Sometimes we } \\
\text { wait for the final conclusion of the medical staff. } \\
\text { Challenges: lack of room, lack of specialists, relationship } \\
\text { with parents of children with SEN, assessment of pupils } \\
\text { with particular problems (lack of methodologies) (L12). }\end{array}$ \\
\hline
\end{tabular}


Psychologist, speech therapist, special educator, social educator, neurologist $(\mathrm{N}=5)$.

Speech therapist, special educator, psychologist, parents $(\mathrm{N}=4)$.
The teamwork principle is to write evaluation findings. We never write conclusions without discussing them. Emphasize to colleagues what worries us (L13).

Discussion of the results takes place in a team of specialists. Each specialist presents the conclusions of their evaluation, formulates the final conclusion, calculates the SEN and prepares recommendations. The findings are given to the parents (L14).

All speech therapists who participated in the study noted, that the child's abilities evaluating specialists cooperate with each other and discuss the achievements with the child's parents and other participants in the educational process who provide assistance to children with special educational needs. The research revealed the importance and opportunities of the implementation of interprofessional coordinated support based on interprofessional collaboration, referring to the experience of speech therapists and special educators providing support to a school-age child with special educational needs and his/her family (Fig. 1).

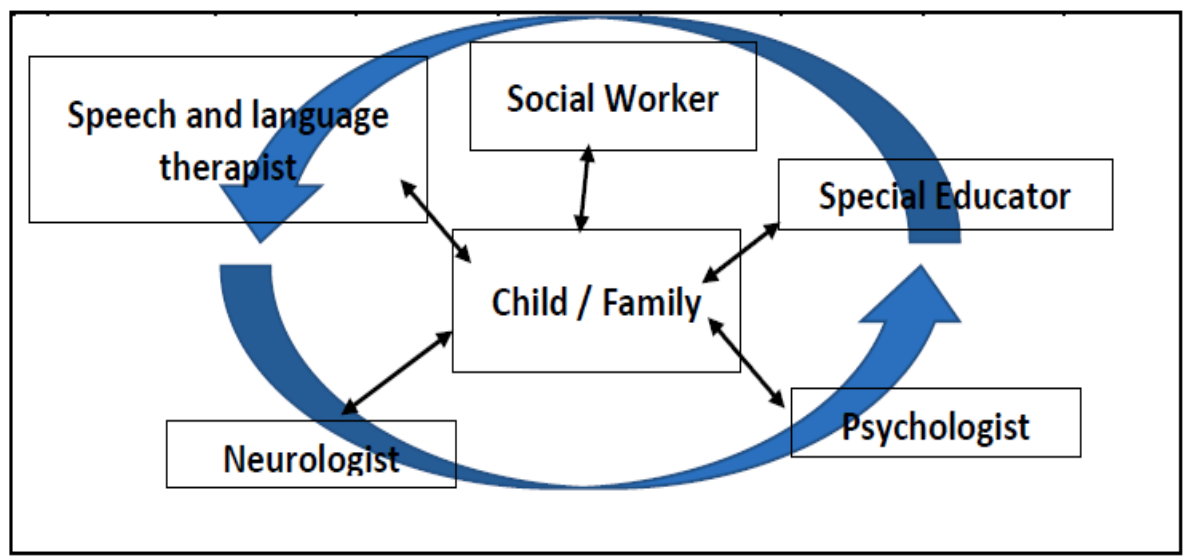

Figure 1 Collaboration-based support provision models (Opinion of Speech therapists)

In our qualitative research, we sought to find out the prevalent patterns of provision in mainstream schools for children with special educational needs. The data obtained from interviews with special educators in mainstream schools are presented in Table 2 and Table 3. 


\section{Table 2 Category: Interprofessional support model (Opinion of special educators)}

\begin{tabular}{|c|c|}
\hline Subcategory (team composition) & Affirmations of cooperation / non-cooperation \\
\hline $\begin{array}{l}\text { Special educator, speech therapist, } \\
\text { social educator, teacher (s), public } \\
\text { health specialist, administration } \\
\text { representative (deputy director for } \\
\text { education or director) }(\mathrm{N}=6) \text {. }\end{array}$ & $\begin{array}{l}\text { We try to get everyone involved in discussing the results of } \\
\text { the child assessment at the PPS, then we meet the child and } \\
\text { their parents at school, and again come together to help } \\
\text { (Sp1). We work together, only by working in a team, and } \\
\text { with the help of regular consultation can we help children } \\
\text { with special educational needs (Sp3). }\end{array}$ \\
\hline $\begin{array}{l}\text { Administrative representative (deputy } \\
\text { director for education, head of unit or } \\
\text { director), speech therapist, special } \\
\text { educator, social } \quad \text { educator, } \\
\text { psychologist, teacher } \quad(\text { s), public } \\
\text { health specialist }(\mathrm{N}=8) \text {. Parents. }\end{array}$ & $\begin{array}{l}\text { Cooperate (Sp6). Based on the child assessment results and } \\
\text { recommendations received from PPS specialists, we } \\
\text { organize the provision of child support. Each practitioner } \\
\text { offers ways to help, and we discuss with the teacher(s) the } \\
\text { principles of adapting curriculum and working methods } \\
\text { (Sp4). Following the advice of PPS professionals, a Child } \\
\text { Welfare Commission meeting is organized to develop a } \\
\text { personalized child support plan (Sp2) with the class or } \\
\text { subject teachers and parents. Findings from a public health } \\
\text { professional, guidance for teachers and parents on helping } \\
\text { children with health, visual, and hearing problems (Sp8) are } \\
\text { also helpful. }\end{array}$ \\
\hline $\begin{array}{l}\text { Administrative representative (deputy } \\
\text { director for education, head of unit or } \\
\text { director), speech therapist, special } \\
\text { educator, two social educators, } \\
\text { teacher(s), assistant teacher }(\mathrm{N}=7) \text {. } \\
\text { Parents. }\end{array}$ & $\begin{array}{l}\text { When we make a plan for individual child, we organize the } \\
\text { provision of special pedagogical and social pedagogical } \\
\text { support for the child together (Sp5). Everyone comments, we } \\
\text { provide help at school and at home (Sp7). The special } \\
\text { educator, together with the teacher(s) and the assistant } \\
\text { teacher, provides directions for the assistance of the child } \\
\text { with special educational needs and discusses general issues } \\
\text { of curriculum adaptation. Consulting with parents (Sp10). }\end{array}$ \\
\hline $\begin{array}{l}\text { Administrative representative (deputy } \\
\text { director for education, head of unit or } \\
\text { director), special educator, speech } \\
\text { therapist, social educator, teacher(s), } \\
\text { public health specialist }(\mathrm{N}=6) \text {. }\end{array}$ & $\begin{array}{l}\text { All professionals cooperate with the teacher(s) to develop a } \\
\text { single child support plan (Sp12). }\end{array}$ \\
\hline $\begin{array}{l}\text { Administrative representative (deputy } \\
\text { director for education or director), } \\
\text { speech therapist, special educator, } \\
\text { social educator, teacher(s) }(\mathrm{N}=5) \text {. } \\
\text { Parents. }\end{array}$ & $\begin{array}{l}\text { The whole team is centered around the child and his parents. } \\
\text { We invite them to a meeting of the Child Welfare } \\
\text { Commission. Talking to the child, parents, agreeing on aids, } \\
\text { duties (Sp9). }\end{array}$ \\
\hline $\begin{array}{l}\text { Administrative representative (deputy } \\
\text { director for education), speech } \\
\text { therapist, social educator, teacher(s), } \\
\text { public health specialist }(\mathrm{N}=5) \text {. } \\
\text { Parents. }\end{array}$ & $\begin{array}{l}\text { Together, we sit down at the Child Welfare Commission } \\
\text { meeting, discuss once more the recommendations of the PPS } \\
\text { specialists, discuss how we will develop tailored programs, } \\
\text { and the ways and methods of working. Here a speech } \\
\text { therapist helps (Sp11). }\end{array}$ \\
\hline $\begin{array}{l}\text { Administrative representative (deputy } \\
\text { director for education), psychologist, } \\
\text { speech therapist, special educator, } \\
\text { assistant teacher, public health } \\
\text { specialist, teacher(s), }(\mathrm{N}=7) \text {. Parents. }\end{array}$ & $\begin{array}{l}\text { We have a large team to support the child. At the Child } \\
\text { Welfare Commission meetings, we discuss how we can help } \\
\text { children with special educational needs. We listen to } \\
\text { everyone's suggestions. The expectations of the child and the } \\
\text { parents are important to us (Sp14). }\end{array}$ \\
\hline
\end{tabular}


Table 3 Category: Multiprofessional support model (Opinion of special educators)

\begin{tabular}{|l|l|}
\hline Subcategory (team composition) & \multicolumn{1}{|c|}{ Affirmations of cooperation / non-cooperation } \\
\hline $\begin{array}{l}\text { Administration representative, special } \\
\text { educator, speech therapist, } \\
\text { psychologist, social educator (N=5). }\end{array}$ & $\begin{array}{l}\text { How can we talk about teamwork when everyone has an } \\
\text { individualistic approach (Sp20). }\end{array}$ \\
\hline $\begin{array}{l}\text { Administration representative, speech } \\
\text { therapist, special educator, social } \\
\text { educator, class teacher (N = 5). } \\
\text { Parents. }\end{array}$ & $\begin{array}{l}\text { Each specialist performs his or her duties individually, and } \\
\text { there are no meetings or meetings. The biggest problem is } \\
\text { collaborating with parents (Sp15). }\end{array}$ \\
\hline $\begin{array}{l}\text { Administration representative, speech } \\
\text { therapist, social educator, teacher(s) } \\
\text { (N = 4). }\end{array}$ & $\begin{array}{l}\text { There is no team in our office, everyone works for } \\
\text { themselves, does not want to share information (Sp16). }\end{array}$ \\
\hline $\begin{array}{l}\text { Administration representative, speech } \\
\text { therapist, teachers (N = 3). }\end{array}$ & $\begin{array}{l}\text { In most cases, the public health professional does not } \\
\text { participate in the work of the Child Welfare Commission, } \\
\text { even though she/he is a member of the Commission. They } \\
\text { say that children's health information is confidential and } \\
\text { cannot be discussed without the parents' permission. There is } \\
\text { alack of special educator, psychologist (Sp17). }\end{array}$ \\
\hline $\begin{array}{l}\text { Speech therapist, educator, } \\
\text { psychologist, teacher (N=4). }\end{array}$ & $\begin{array}{l}\text { The psychologist keeps everything, related to the education } \\
\text { of the child, a confidential (Sp18). }\end{array}$ \\
\hline $\begin{array}{l}\text { Speech therapist, social educator, } \\
\text { psychologist, teacher (N=4). }\end{array}$ & $\begin{array}{l}\text { There is no team work in the institution, but I would very } \\
\text { much like to have someone to talk to about the education of } \\
\text { children with special educational needs (Sp19). }\end{array}$ \\
\hline $\begin{array}{l}\text { Speech therapist, psychologist, } \\
\text { teacher, special educator (N=4). }\end{array}$ & $\begin{array}{l}\text { All specialists work in their offices, reluctant to } \\
\text { communicate, and each individually develops disorder } \\
\text { recovery programs for children. Lack of administrative } \\
\text { support (Sp13). }\end{array}$ \\
\hline
\end{tabular}

There are several models of assistance in mainstream education. The data in Table 2 and Table 3 shows that there is a predominantly interprofessional model of support for children with special educational needs in mainstream schools, where members of the School Child Welfare Committee actively cooperate with teachers in developing individual child support plans, alternative working methods and teaching / learning methods. Special educators noted that children by themselves are actively encouraged to participate in this process. However, more than one third of special education teachers noted that their school still has a multiprofessional support for a child with SEN, where specialists have little cooperation with other pedagogical, social or psychological specialists. Specialists who is working with a child do not always receive the support of the administration. Most of special educators indicated that there was a lack of involvement of school-based public aid specialists in the work of the Child Welfare Commission.

The study found that children with SEN receives an assistance from members of the Child Welfare Commission (speech therapists, special educators, psychologists, teacher assistants, public health specialists) and teachers. A 
representative of the administration directs the activities of the School's Child Welfare Commission. It has been noted that there is still a shortage of psychologists, teacher assistants and special educators in mainstream schools.

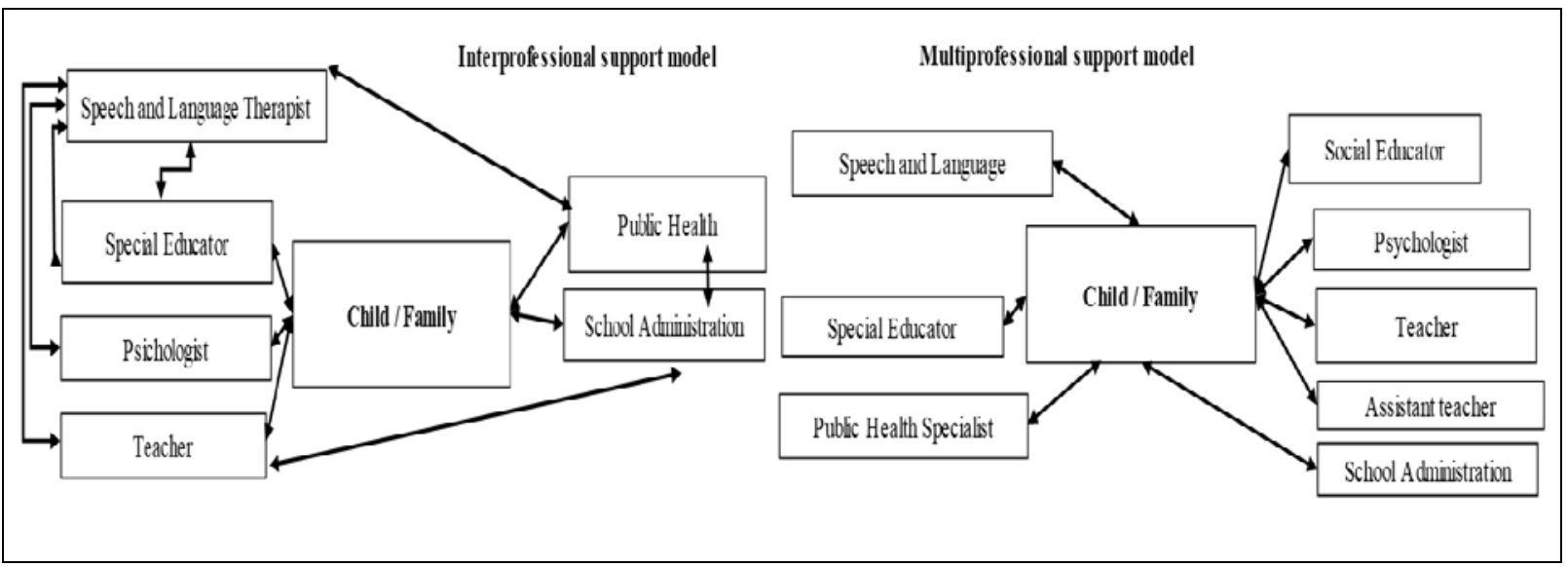

Figure 2 Collaboration-based support provision models (opinion of special educators)

The speech therapists and special educators working in the PPS and mainstream schools noted that in order to help a person with disorders, it is important to stimulate family powers meant for cognitive acceptance of a problem or disorder, the development of self-confidence, and the increase of the feeling of control and sense. Family-centred support is based on the attitude that all family members should be involved into the process of assessment and support.

\section{Conclusions}

1. The research has revealed that in practice the beginnings of interprofessional support provision model are observed. Speech therapists working in Pedagogical Psychological Services noted that in their practice is dominated by an interprofessional aid delivery model, but more than one-third of the special educators surveyed noted, that the multiprofessional aid model for children with special educational needs is still predominant in mainstream schools.

2. According to children support specialists, while providing support it is important to encourage specialists' and pedagogues' effective communication and collaboration with a child and his/her family, to teach them suitable strategies of solving the problem, to give individual recommendations taking the unique needs of the child and the family into account. 
3. One of important factors of involvement is counseling that positively influences the interaction of family members, helps to better understand the current situation and the indicators of the expected behaviour.

\section{References}

Ališauskienė, S. (2010). Early Childhood Intervention in Lithuania: Organisation and Challenges. International Journal of Early Childhood Special Education, 2(2), 124-135.

Baker, K., \& Donnelly, M. (2001). The Social Experiences of Children with Disability and the Influence of Environment: A Framework for Intervention. Disability \& Society, 16(1), 71-85.

Carpenter, B. (2007). The Impetus for Family-centred Early Childhood Intervention. Journal compilation, Child: Care, Health and Development, 33(6), 664-669.

Davis, K., \& Gavidia-Payne, S. (2009). The impact of child, family, and professional support characteristics on the quality of life in families of young children with disabilities [201710-11]. Retrieved from https://www.ncbi.nlm.nih.gov/pubmed/19404836

Hall, P., \& Weaver, L. (2001). Interdisciplinary Education and Teamwork: A Long and Winding Road. Medical Education, 35, 867-875.

Hammick, M., Freeth, D., Copperman, J., \& Goodsman, D. (2009). Being Interprofessional. Polity.

Kairiene, D. (2012). The collaborative culture in interprofessional teams, providing early support for young children and their families. (Unpublished doctoral dissertation, Šiauliai University).

Kantanavičiūtè, R. (2018). Inter-professional support to an early age stuttering child and one's family while applying the multidimensional intervention. (Unpublished doctoral dissertation, Šiauliai University).

Kauffman, J., \& Hallahan, D.P. (2005). Special Education: What It Is and Why We Need It. Pearson: Allyn and Bacon.

Miltenienè, L., \& Melienè, R. (2010). Forms of special education in the context of inclusive education: the dutch experience. Special Education, 1(22), 133-140.

Nolte, J. (2005). Enhancing Interdisciplinary Collaboration in Primary Health Care. Primary Health Care: A Framework That Fits. EICP.

Olenick, M., Allen, L.R., \& Smego, R.A. (2010). Interprofessional Education: A Concept Analysis, Advances in Medical Education and Practice, 1, 75-84.

Reeves, S., Zwarenstein, M., Goldman, J., Barr, H., et al. (2010). The Effectiveness of Interprofessional Education: Key Findings from a New Systematic Review, Journal of Interprofessional Care, 24(3), 230-241.

Rokusek, C. (1995). An Introduction to the concept of interdisciplinary practice. In B.A. Thyer \& N. Kropf (Eds.), Developmental disabilities: Handbook for interdisciplinary practice. Campbridge, MA: Brookline books.

Soriano, V. (2005). Ankstyvoji intervencija vaikystejje: situacijos Europoje analizé, pagrindiniai aspektai ir rekomendacijos. Vilnius: European Agency for Development in Special Needs Education.

Vanclay, L. (2003). Supporting Families an Interprofessional Approach? In A. Leathard (Ed.), Interprofessional Collaboration: from Policy to Practice in Health and Social Care (pp. 158-171). London and New York: Routledge.

Villa, R.A., \& Thousand, J.S. (2005). Creating an Inclusive School (2 ed.). USA: ASCD. 